International Journal of Instruction e-ISSN: 1308-1470 • www.e-iji.net

Article submission code: 20201014090820

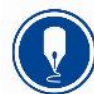

October $2021 \bullet$ Vol.14, No.4

p-ISSN: 1694-609X

pp. 483-502

Received: 14/10/2020

Revision: 28/03/2021
Accepted: 22/04/2021

OnlineFirst: 11/08/2021

\title{
Algebra Dominoes Game: Re-Designing Mathematics Learning During the Covid-19 Pandemic
}

\section{Uba Umbara}

Dr., Department of Mathematics Education, STKIP Muhammadiyah Kuningan, Indonesia, uba.bara@upmk.ac.id

\section{Munir}

Prof., Department of Computer Science, Universitas Pendidikan Indonesia, munir@upi.edu

\section{Rudi Susilana}

Dr., Department of Educational Technology, Universitas Pendidikan Indonesia, rudi_susilana@upi.edu

\section{EFW Puadi}

Department of Mathematics Education, STKIP Muhammadiyah Kuningan, Indonesia, evanfarhanwahyupuadi@upmk.ac.id

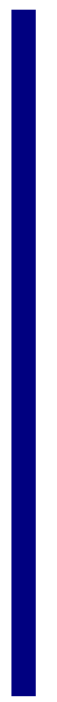

This study discusses the development and effectiveness of game instruction on mathematical communication skills. This feature, developed using Microsoft PowerPoint, provides learning instructions with a chain game called algebra dominoes. The principles of independent learning and mastery learning are strategies in learning to ensure that students can learn independently during the Covid-19 pandemic. This study was developed based on Research \& Development with systematic, comprehensive, and coherent stages through strict quality control through the Analysis, Design, Development, Implementation, and Evaluation (ADDIE) design. The results showed that the domino algebra developed was feasible to be mass-produced and used in mathematics learning based on expert validity tests, user practicality tests, and effectiveness tests on students' mathematical communication skills. The effectiveness test results show that the algebraic dominoes games developed are proven to be useful in developing students' mathematical communication skills. The results showed that the increase in students' mathematical communication skills in the experimental class was better than in the control class. The use of game instructions can be the main alternative in designing mathematics learning during the Covid-19 pandemic, both online and offline.

Keywords: ADDIE, algebra dominoes game, computer-assisted instruction, game instruction, mathematical communication, mathematics learning

Citation: Umbara, U., Munir., Susilana, R., \& Puadi, EFW (2021). Algebra dominoes game: Redesigning mathematics learning during the covid-19 pandemic. International Journal of Instruction, 14(4), 483-502. https://doi.org/10.29333/iji.2021.14429a 


\section{INTRODUCTION}

Until now, the Covid-19 outbreak is still a frightening ghost for humanity around the world. Since December 2019, in Wuhan, China, the virus has rapidly spread throughout the world. On March 11, 2020, the World Health Organization (WHO) declared this outbreak a global pandemic (Sudarsana et al., 2020). This virus has spread very quickly to almost all countries. Almost all countries have implemented social restriction policies to prevent the spread of the coronavirus, including Indonesia. Indonesia has been one of the countries affected by the Covid-19 outbreak since March 2, 2020. In line with the guidelines for containing the virus, the Indonesian government has implemented a social distancing policy to suppress this virus's spread.

Through the Ministry of Education and Culture, the Indonesian government decided to implement a policy of implementing learning methods with an online system starting in mid-March 2020. Teachers are required to ensure teaching and learning activities continue even though students are at home. It prompted the teachers to design and develop innovative instructional media for learning. Innovation is needed to support online distance learning-based so that students can be directed to learn independently. However, mathematical concepts that are abstract, structured, and systematic can become obstacles for students. Students tend to need teacher guidance to learn mathematical concepts. In connection with this, the learning process of mathematics requires learning media that can minimise student difficulties and bridge communication in learning carried out online and offline. The use of media in learning has the primary function as a communication tool. As a means of communication between teachers and students, instructional media can increase the effectiveness and maximum achievement of learning objectives (Newby et al., 2006), which can be done through information and communication technology (ICT).

In general, ICT is often used as an "add-on" to demonstrate the latest programs (Richards, 2005), which can anticipate teacher ambiguity in explaining material concepts that may appear in the delivery of teaching materials (Umbara et al., 2020), so the use of ICT has excellent potential as a pedagogical tool if it can be adequately utilised (Cooper \& Brna, 2002). Utilising ICT in learning is an innovation in education in the context of 21st-century learning, which is marked by the use of information and communication technology. 21st-century learning as a means of preparing the 21st century generation can be done by adapting the advances in ICT that are developing rapidly. Students in 21 st-century learning must be prepared and given the opportunity and required to develop their skills in mastering information and communication technology so that they can become intelligent, independent, superior, and uncompromising individuals who can survive in the 21 st century.

As systems and learning approaches change, entering the century 21 tasks and teachers' roles influence the learning process. In this case, the teacher has a vital fundamental role in guiding, directing, and educating students in the learning process (Davies \& Ellison, 1992). One of the ICT learning models that can be developed to guide, direct, and educate students is a game model. The game model has the main characteristics of collaborating serious learning and interactive entertainment to bring about cognitive 
changes (Prensky, 2001). The use of game models is expected to foster an interest in learning and reduce student boredom in learning the material. Interest is needed to integrate ICT in teaching to make it more useful (Erhel \& Jamet, 2013). Based on this, this research was conducted to develop game-based multimedia. Based on the development of ICT-based learning with a game model known as Digital Game-Based Learning (DGBL). DGBL has become a reference medium in education for the past few years through a form of simulation that allows students to practice their competence in a virtual environment (Erhel \& Jamet, 2013), which can make the learning environment interesting, meaningful, complex, and fun (Kirkley et al., 2005).

Several previous studies stated that the use of game models could provide learning motivation to students (Gee, 2005), overcome various learning weaknesses (van Oostendorp et al., 2014), help students carry out cognitive processes through the mobilisation of concepts designed in a game (Erhel \& Jamet, 2013). Meanwhile, in learning mathematics, several research results showed that game models could improve mathematical representation ability (Umbara et al., 2019) and mathematical comprehension ability (Umbara et al., 2020), and increase the acquisition of mathematical knowledge and maintain student motivation in algebra (Bai et al., 2012), has a positive effect on the development of number sense for fourth-grade students (Nejem \& Muhanna, 2013).

However, other studies on the use of games in learning contradict the results of the above research because they do not have a positive effect, there is a disparity between groups of students, and the difference in their effect on improving student mathematics achievement. Researches that cause this disparity includes: male students are more enthusiastic than female students, so that male students tend to be able to recognise mathematics in the game (De Jean et al., 1999), no difference in algebraic performance between male and female students (Haynes, 2000), the quality of interactions with similar instructional goals between teachers and students was lower during the game than during the non-game segment (Heshmati et al., 2018) and not significantly different in facilitating students' cognitive math test performance and meta-cognitive awareness (Ke, 2008).

Several different research results that we have presented above provide insight into the importance of additional research. Additional studies are needed to investigate further the effect of computer games on students' mathematical abilities. In this study, we tried to develop interactive game-based learning to encourage students' learning motivation and facilitate the development of students' mathematical abilities. The game developed in this study is named algebra dominoes. Algebra dominoes is a game designed for use by junior high school students in learning algebra. We use Research \& Development design in developing interactive game-assisted learning to ensure feasibility based on expert and user judgment. To test the effectiveness of the games being developed, we tested them to increase students' mathematical communication skills. Based on this, the purpose of this study is to describe the process of developing domino algebra, the feasibility of dominoes algebra as interactive game-based learning, and to test the effectiveness of dominoes algebra on students' mathematical communication skills. 
Based on this framework, the formulation of the problem is as follows: (1) describe the dominoes algebra development process (2) analyze the feasibility of dominoes algebra as interactive game-assisted learning, and (3) describe the effectiveness of dominoes algebra on students' mathematical communication skills in terms of model learning and early math skills (EMS).

\section{Literature Review}

\section{Computer assisted instruction}

Computer-Assisted Instruction (CAI) is learning that is carried out using ICT devices. CAI's use emphasises communication between humans and computer devices designed with a particular model to maximise learning independence and overcome student boredom in learning. A simple definition of CAI is conveyed by Alan B. Salisbury, who states that CAI is an interaction between humans and computers in learning that is carried out without the intervention of the instructor (Zhang et al., 2007) which emphasises an activity-based learning approach (Thomas \& Knezek, 2002). Traditional mathematics learning cannot be denied the possibility of causing boredom for students. ICT is often used in the latest demonstration programs in learning in the digital world that serve as an anticipation of student saturation factors for teacher rhetoric in traditional learning (Cuban, 2009).

Without the intervention intended by Alan B. Salisbury above, it does not mean that the teacher entirely allows students to learn according to their wishes. The teacher's role remains an essential part of the CAI learning model. As a CAI facilitator, the teacher's role is significant to guide students in finding mathematical concepts, ideas, and procedures. The teacher's role can be carried out through intensive two-way communication. In general, without the teacher's role, ICT learning has the potential to be less developed so that direct interaction through pedagogical guidance by the teacher is necessary (Plowman \& Stephen, 2003). In particular, it was stated that CAl would be more effective when used as a complement to traditional teaching rather than as a substitute. In other words, CAI used in other teaching strategies was more beneficial for student learning in science subjects (Bayraktar, 2001).

The use of ICT in science learning serves to support reasoning ability (Chang et al., 2008), gain more mastery of geometric concepts (Funkhouser, 2002), increase participation and higher learning outcomes in mathematics learning (De Witte et al., 2015), and strengthen their understanding of statistical material (González \& Birch, 2000). The CAI model used in learning effects of achievement, attitudes and mathematical retention (Pilli \& Aksu, 2013), increase the initial learning process statistics (Basturk, 2005), provide significant benefits to literacy ability (Macaruso \& Walker, 2008), even useful in learning for students with autism (Pennington, 2010) as well as on academic performance in universities (Christmann \& Badgett, 2000).

The most significant thing in developing CAI to support learning effectively is the substance of the suitability of the content, the substance of the material, the feasibility of presentation, and the contextual assessment presented coherently. When substantial material is delivered coherently, learning can effectively and efficiently be done (Munir 
et al., 2016). The CAI development should not focus on attractive display and content as it can reduce the communication process between teachers and students (Umbara et al., 2019). Instruction, developed with CAI, can help students control the speed at which information is presented (Frederickson et al., 2005). It can be used to see students' skills and knowledge (Anohina, 2005).

\section{Game rationalization in mathematics learning}

In the world of education, including mathematics learning, games in learning are not new. Amid advances in technology and information, teachers can develop games very quickly because of the availability of adequate hardware and software. Mathematics teachers can maximise this opportunity to provide a different learning experience for students, especially to maintain students' enthusiasm for learning mathematics and insert entertainment elements to erode student boredom in learning mathematics. Games are a valuable addition to any method implementation plan for teaching mathematics (Ernest, 1986). In general, game-based learning has the main characteristic of collaborating serious learning and interactive entertainment to bring about cognitive change for students (Prensky, 2001).

In principle, the success of learning mathematics is very much dependent on the active involvement of students. Student involvement in mathematics learning is crucial so that learning can take place optimally. As a facilitator in learning mathematics, the teacher can seek to maximise student involvement actively as a subject in mathematics class. This principle is compatible with playing games that require the involvement of the players. The principles and strategies inherent in teaching ICT emphasise an activitybased approach (Thomas \& Knezek, 2002). Games are not passively played, so students must consciously be involved in playing them, especially if they want to win the game. Games encourage children's active interactions, increase their motivation, and make them more receptive to learning (Ernest, 1986).

The receptive nature of learning is allegedly due to the pleasure factor in learning. The principle of learning while playing is the main principle highlighted in the mathematics learning process. Pleasure can be defined as something that occurs as a result of three sources either partially or integrally: feelings of happiness, involvement, and/or meaningful activity (Kirkley \& Kirkley, 2005), as the feedback provided by the brain when absorbing patterns to achieve predetermined learning goals (Koster, 2013). Thus, games in learning contain elements of challenges for students to continuously try, understand the game's flow, complete the game, and understand the concepts of the material in the game repeatedly until they master the concept of the material in the game.

Math games that are fun, engaging, and enriching learning experiences can help students overcome any ambivalent feelings they may have about concepts and subject areas (Heshmati et al., 2018). The learning experience felt by students in learning mathematics using games is undoubtedly different from ordinary learning. Games can be designed to provide practice of math problems that are different from ordinary skill practice. Games designed to be played individually in the classroom can allow students to recognise 
patterns in recognising mathematical concepts in a structured manner but can still provide opportunities for interaction between students. They carry out interaction about how to complete the challenges in the game. Thus, introducing games into math classrooms can be a way to encourage collaboration (Ernest, 1986).

\section{Mathematical communication ability}

Mathematics is a symbolic language consisting of several notations, symbols, and special terms. Therefore, efforts are made to ensure that mathematical concepts and ideas can be properly communicated to be understood properly and correctly. The form of multidirectional communication in mathematics learning is an ideal form that can be used to communicate, convey, and express mathematical ideas. Therefore, mathematical communication skills play an important role and are among the five process standards in mathematics education emphasised by the National Council of Teachers of Mathematics (NCTM, 2000). Mathematical communication is a central force that can be used by students in formulating mathematical concepts and strategies (Greenes \& Schulman, 1996). The importance of students' mathematical communication ability is so that they can convey ideas, ideas, and the results of their thoughts to others effectively. Communication needs to be developed in learning mathematics to think and find patterns, social activities, student interactions, and teacher and student interactions. (Baroody \& Coslick, 1993).

Communication is a way that can be used to share thoughts, ideas and clarify understanding of mathematical concepts. Mathematical communication standards highlight the importance of students' ability to communicate mathematical thinking coherently to peers and teachers. Mathematical communication standards can also be expressed as students' needs in expressing mathematical thoughts and ideas through mathematical language (Whitin \& Whitin, 2003);(Rubenstein \& Thompson, 2002). Based on the importance of mathematical communication's role and function, it is essential to recognise the aspects and forms of mathematical communication. There are five aspects of communication: representation, listening, reading, discussion, and writing (Baroody \& Coslick, 1993). Furthermore, mathematical communication consists of at least four general categories: unidirectional communication, contributive, reflective, and instructive (Brendefur \& Frykholm, 2000).

These aspects and forms of mathematical communication can be considered in developing mathematics learning to support student involvement, empower student thinking, increase awareness of the importance of building knowledge, and encourage active student participation in mathematics learning. There are several strategies that teachers can do to achieve this goal, including (1) proposing various tasks that encourage discussion; (2) designing an environment conducive to the successful discussion; (3) arranging questions that can provide a stimulus to students to explain their thinking and the reasons for the concepts they understand; and (4) encourage students to process ideas (Clark et al., 2005). Mathematical communication is one of the standard processes in learning that can be developed either integrally with other mathematical abilities or partially. Communication ability can be optimally improved with proper treatment by the teacher. 


\section{METHOD}

This study uses the ADDIE model instructional design. ADDIE is an acronym for Analysis, Design, Development, Implementation, and Evaluation, the concept of product development, and a fundamental process for creating adequate learning resources (Branch, 2009). This model was chosen because it is considered to have organised, systematic, measurable, and interactive elements in meeting learning development objectives, including game-based instructional learning. The stages of implementing the ADDIE model are shown in Figure 1 below.

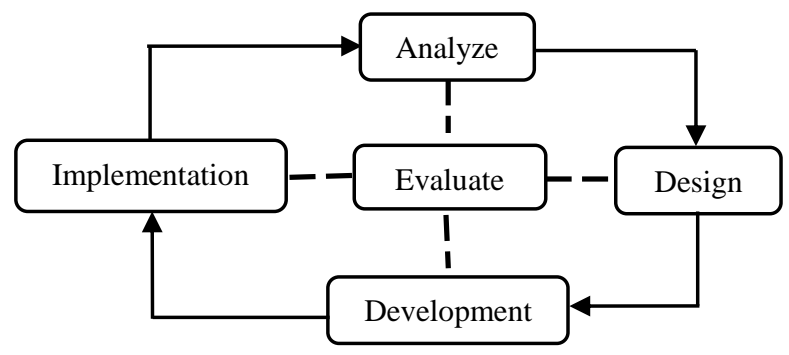

Figure 1

ADDIE model (Branch, 2009)

The instructional design stages can be explained based on the concepts and general instructional design procedures performed (Branch, 2009), such as the following.

1. Analyse is the stage of identifying possible causes of performance gaps.

2. Design is a verification stage of the desired performance and the appropriate testing method.

3. Development is a stage in producing and validating learning resources.

4. Implementation is a stage that can be done in preparing a learning environment and involving students.

5. Evaluate is a process in assessing product quality and instructional processes, before and after implementation.

At the implementation stage, the researcher conducted trials on applying learning media that had been developed directly. Media testing consists of validity testing by experts and practicality testing by users. Expert validity tests are carried out by subject matter content experts and media experts using a closed questionnaire but equipped with a suggestion and criticism column to accommodate if the experts provide input on improving media development. The use of questionnaires can provide a wealth of information from individual samples, for which written response instruments are generally preferred over performance instruments (Fraenkel et al., 2011). The determination of the quantitative expert judgment is based on the following criteria. 
Table 1

Categories of multimedia validation

\begin{tabular}{ll}
\hline Interval Value & Category \\
\hline $4.01-5.00$ & Very valid \\
\hline $3.01-4.00$ & Valid \\
\hline $2.01-3.00$ & Less valid \\
\hline $1.00-2.00$ & Not valid \\
\hline
\end{tabular}

The minimum eligibility category of expert validation used in the study is the valid category. The product developed is considered suitable for use as a learning medium if the final (overall) assessment results on every aspect such as learning aspects, content/material aspects, display aspects, and technical aspects are considered valid by experts. Media experts are tasked with evaluating the media developed by conducting validation based on the suitability of flowcharts, storyboards, soft anchor engineering aspects, audiovisual communication aspects, presentation aspects, and display aspects. Meanwhile, content experts validate based on competence and learning objectives, conformity with material indicators, quality of material content, and test items quality. Practicality tests were carried out on students as users using questionnaire instruments and structured interview sheets. Students' practicality test is carried out in three stages consisting of one on one trial evaluation, small group evaluation, and field evaluation.

At the evaluation stage, the researcher conducted a multimedia effectiveness test on students' mathematical abilities. The mathematical ability chosen to test the media's effectiveness in this study is the students' mathematical communication skills. Mathematical communication skills are chosen based on consideration because they are a central force that can be used to formulate mathematical concepts and strategies so that they can be used to share thoughts, ideas and clarify understanding of mathematical concepts coherently with peers and teachers. At the evaluation stage, the researcher used a quasi-experimental design, namely the pretest-posttest control group design. Mathematical communication skills questions are arranged based on aspects and indicators of mathematical communication skills, which consist of: (1) written text; (2) drawing; and (3) mathematical expressions (Kusumah et al., 2020).

Quantitative data analysis is conducted to prove whether there is an increase in mathematical communication skills based on the learning model used and the EMS category. The research sample consisted of 80 students who were selected by using nonprobability samples using purposive sampling type. This technique is carried out based on students' characteristics in that class who have heterogeneous EMS categories. The experimental class consisted of 39 students, nine students in the high EMS category, 20 students in the moderate EMS category, and ten low EMS categories. The control class consisted of 41 students, 11 students in the high EMS category, 22 students in the moderate EMS category, and eight students in the low EMS category.

Data analysis at this evaluation stage was carried out using a two-way ANOVA test involving the General Linear Model (GLM) Univariate Analysis. Hypothesis testing is carried out with a significance level of 0.05 . The five stages of media development are stages be carried out systematically in the context of developing multimedia learning so 
that the media's feasibility can be appropriately guaranteed. The entire process of media research and development was carried out at the State Islamic Junior High School (Madrasah Tsanawiyah Negeri) 3 Kuningan with a development duration of \pm five months, starting on February 11 - July 30, 2020.

\section{FINDINGS}

The results of the research will be described in two parts. The first part will describe the algebra dominoes development process, and the second part will describe the results of its effect on students' mathematical communication skills.

\section{Algebra dominoes game development process}

Analyse

Problem identification needs analysis, and analysis of the types of tasks was carried out using questionnaire sheets, in-depth interviews, and observations. The main problems identified in the teaching and learning carried out by teachers and students are learning media that is relatively rarely used. Students' ability to understand the abstract mathematical concept about mathematical concepts tends to be stagnant, and students often feel bored in the learning process. The needs analysis shows the importance of redesigning the learning process by maximising the use of learning media. The observation result of the implementation of learning indicates that the use of media is still limited in learning, so that it results in a lack of enthusiasm for students. The results of observations on learning support facilities obtained good results, the school's computer laboratory facilities were adequate both in terms of the number and quality of the computer equipment. However, these facilities cannot be used optimally for various reasons. Based on this analysis, the researcher decided to re-design the learning model and develop multimedia learning that is expected to facilitate mathematics learning optimally. The learning model was developed with the Computer-Assisted Instruction (CAI) type game instruction model. Researchers use Microsoft PowerPoint as software development. The use of Microsoft PowerPoint was based on several aspects, including ease, familiarity, and compatibility.

\section{Design}

At the learning design stage, the researcher determines the competencies, indicators, learning objectives, compiles learning materials, arranges structured assignments, and compiles test questions for mathematical communication skills. The CAI model was developed based on the principles of self-learning and mastery through game instructions. Learning is carried out based on understanding in a systematic and structured manner, from simple concepts to complex concepts. The teacher provides much stimulation to student understanding, both inductively and deductively. Students are guided to use games that have been developed by first understanding the learning objectives, game rules, and game instructions. 


\section{Development}

At this stage of development, the researcher carried out the media production process as an embodiment of ICT learning with the CAI model intended in this study. The initial process of developing multimedia development is based on game learning principles, which are carried out with compiling stages: an outline of media development, flowcharts, storyboards, entering test questions into the computer, and ending with a modular test. Modular testing is carried out to test the functionally produced media based on small interconnected parts so that it can be ascertained that the developed multimedia can be used. At this stage, the researcher produces multimedia in the form of a prototype. The mention of multimedia is developed as a prototype because it still has to go through the testing phase at the implementation stage before the product is produced as the final product. The application named "Aldo" was developed to make pronunciation more manageable, an acronym for algebra dominoes.

\section{Implementation}

The implementation stage begins with a validity test by an expert. Four experts tested the validity of namely: two media experts and two material experts. The results of the expert validation are shown in Table 2 below.

Table 2

Validation results for algebra dominoes development

\begin{tabular}{lll}
\hline Validator & Average value & Category \\
\hline Multimedia Expert I & 4,56 & Very Valid \\
\hline Multimedia Expert II & 4,68 & Very Valid \\
\hline Content Expert I & 4,84 & Very Valid \\
\hline Content Expert II & 4,78 & Very Valid \\
\hline Average & 4.71 & \\
\hline
\end{tabular}

As illustrated in Table 2, it is known that all the experts gave a high score with an average of 4.71 , so that it could be categorised as very valid. The results of this assessment indicate that the experts are satisfied with the multimedia developed. However, experts still provide some notes of improvement in the comments column provided in a closed questionnaire. Two related media experts gave suggestions: the appearance of the navigation buttons, some symbols used must be replaced with writing so that they are easily recognised, and aspects of unity in the use of visual and audio. Some of the suggestions given by the two material experts were related to instructions on less operational game rules, variations in the difficulty level of the questions, adjustment of the time provided with the difficulty level of the questions, and adding feedback with language that can motivate students. Based on these suggestions, the researcher then made several improvements related to four things that were the experts' focus.

After improving the media based on experts' suggestions, the media was then tried out on students in the form of one-by-one trial evaluations, small group evaluations, and field evaluations. Of the three trials, students complained about the readability of the 
questions, so that most students suggested that the display of numbers and background colours be adjusted so that they were easy to read, added playtime, and added more games. However, most of the students responded very well to the games developed. Some of the right responses delivered by students include a game flow that is easy to understand, can encourage them to study independently, students feel there are challenges in playing games, and students feel enthusiastic about learning mathematics. The multimedia display developed in this study is shown in Figure 2.
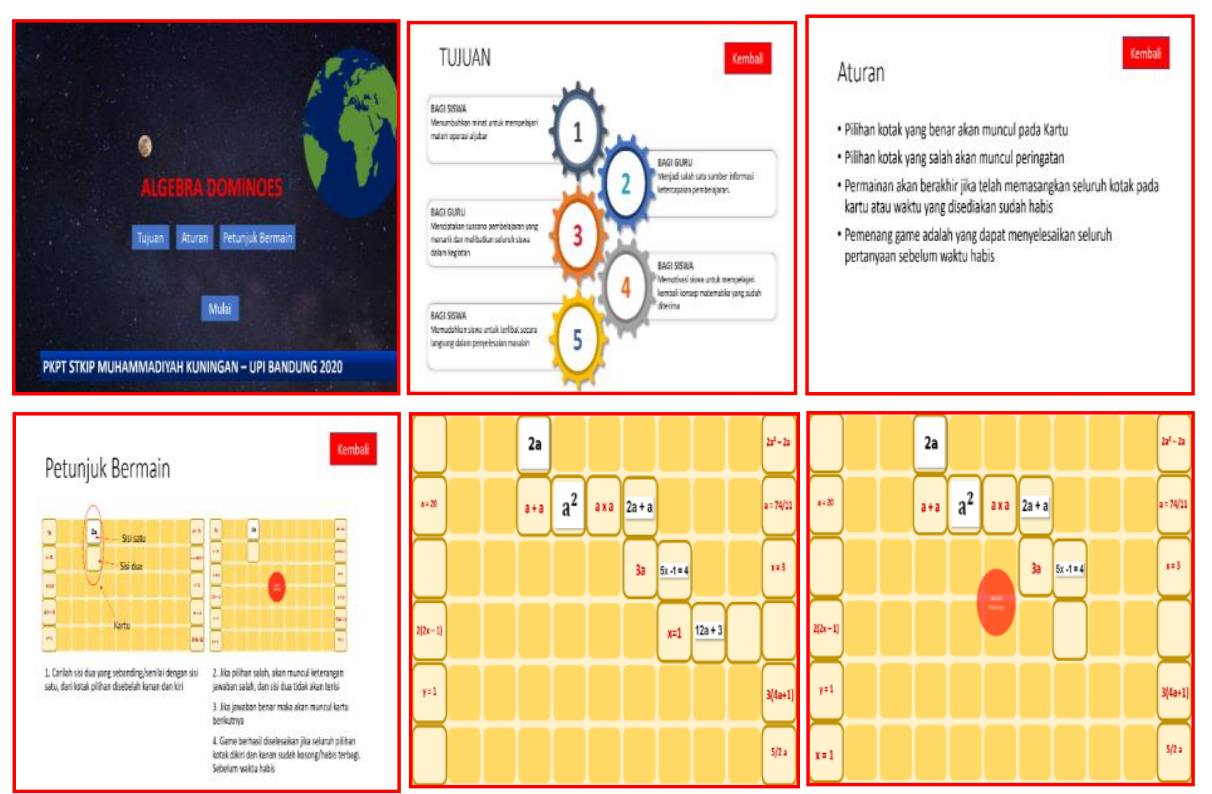

Figure 2

Display of algebra dominoes game

Figure 2 that is shown, is a view of the final product of the developed algebra dominoes. The picture above consists of the initial display, objectives, game rules, instructions for play, examples of displays when students answer incorrectly, and displays when the game continues because the students succeeded in answering the questions.

\section{Results of the effectiveness test for algebra dominoes game (Evaluate)}

Evaluation is carried out to test the effectiveness of using the CAI type game instruction on students' mathematical communication ability in learning algebra. Data analysis was carried out to compare mathematical communication ability between the experimental group (the class has given learning with the CAI type Game Instruction model/using the Algebra Dominoes game) and the control group (the class has given the Conventional Learning Model/CLM) and the differences in the improvement of mathematical communication ability based on the level of EMS category. The hypothesis to test the comparison of the increase in mathematical communication skills is described as: 
1. The increase in students' mathematical communication ability in the experimental group is better than those of the control group.

2. There is a significant difference in the increase in mathematical communication ability between students with high, medium, and low ability levels.

The two hypotheses above will be proven by a two-way analysis of variance (ANOVA) with GLM-Univariate. The analysis results are shown in Table 4.

Table 4

Analysis of data variance on the increase of mathematics communication ability based on previous mathematics learning models and ability

\begin{tabular}{lllllll}
\hline Source & $\begin{array}{l}\text { Type III Sum of } \\
\text { Squares }\end{array}$ & df & Mean Square & F & Sig. & $\begin{array}{l}\text { Partial Eta } \\
\text { Squared }\end{array}$ \\
\hline Corrected Model & $1.555^{\mathrm{a}}$ & 5 & .311 & 53.438 & .000 & .783 \\
\hline Intercept & 19.565 & 1 & 19.565 & 3361.806 & .000 & .978 \\
\hline Model & .903 & 1 & .903 & 155.216 & .000 & .677 \\
\hline PAM & .487 & 2 & .243 & 41.798 & .000 & .530 \\
\hline Error & .431 & 74 & .006 & & & \\
\hline Total & 23.816 & 80 & & & & \\
\hline
\end{tabular}

Based on the calculations in table 4 above to test the first hypothesis, the significance value (Sig.) Is obtained of $0.000<\alpha=0.05$ and $F_{\text {count }}=155.216$ is greater than $F_{\text {table }}=$ 3.12 at the significance level $\alpha=0.05$ with $2 \mathrm{df}\left(\mathrm{F}_{0,05(74)}=3.12\right)$ so that $\mathrm{H}_{0}$ is rejected. It means that the increase in mathematical communication ability of students who studied in the experimental group was better than those of the control group. Furthermore, to test the second hypothesis, a significance value (Sig.) Of $0.000>\alpha=0.05$ and $\mathrm{F}_{\text {count }}=$ 41.798 is greater than $F_{\text {table }}=3.12$ at the significance level $\alpha=0.05$ with $\mathrm{df}\left(\mathrm{F}_{0,05(74)}=\right.$ 3.12) so that $\mathrm{H}_{0}$ is rejected. There are differences in the improvement of students' mathematical communication ability between high, medium, and low-ability students.

\section{DISCUSSION}

Based on the research results that have been shown previously, it can be concluded that the learning developed with the algebra dominoes game is suitable for developing students' mathematical communication skills and may be suitable for learning mathematics. This model's feasibility can be seen from the results of expert validation tests, practicality tests, and effectiveness tests carried out in stages according to the ADDIE design. The expert validation test results showed that the media was feasible to continue at the practicality test stage by teachers and students because it exceeded the minimum standard value of feasibility. Suggestions from two media experts are generalised by emphasising the feasibility of the content and substance of the material and the feasibility of language.

Based on the practicality test results, students showed good responses to the games developed by the researcher. The researcher accommodated some complaints that were considered criticism and suggestions from students to improve. The improvements made after the practicality test can be generalised as visual aspects and software engineering 
aspects. Students show good enthusiasm when trying to use the game and express their interest in learning to use game interaction. Most students admit that they like the games used in learning so that learning tends to be active and interactive. Computer games provide students with the preferred format for experiencing active learning through simulated visualisations, authentic problem solving, and instant feedback (Huang \& Ke, 2009).

It cannot be denied that most mathematics learning revolves around providing practice to children. Exercises usually aim to provide scaffolding of newly acquired ability and develop extra ability. However, the exercises that are carried out in class tend to be boring for students because they are usually mechanistic and structuralistic. When teachers explain concepts through narratives or examples conducted in regular classroom settings, students may become confused or get lost in abstract cognitive processes (Bai et al., 2012). Presenting new formulas in mathematics learning by modifying mechanistic and structuralistic approaches is the main result of this research. One of the benefits of developing digital games in mathematics learning is to help present abstract mathematical concepts visually (Heckenberg et al., 2004) so that it can help students understand the concept logically (Sanchez-Palencia, 1980) and generate mental models of mathematical concepts (Lopez-Morteo \& López, 2007).

The game known as algebra dominoes in this study in presenting mathematical concepts visually is the main factor that causes students' enthusiasm in participating in mathematics learning. Algebra dominoes itself is a type of simulation game developed based on domino games in everyday life. Simulation games are one of the innovations in-game content traditionally considered educational, as they represent real-world phenomena by placing players in a semi-realistic context where they can use a variety of knowledge to succeed (Tobias et al., 2011). Although this game originates from China, this game is quite familiar and is often played in Indonesia. This algebra dominoes game is a cumulative chain game. The system developed in domino algebra is also able to build learning models with self-regulated learning to form student learning habits outside the classroom. In connection with this self-regulated learning model concept, the researcher claims that the game instruction type CAI model can be used as an alternative solution to learning mathematics during the Covid-19 pandemic.

Learning that is designed in a systematic, structured, and chain manner can make it easier for students to learn mathematical concepts as a whole and comprehensively independently, especially during the Covid-19 pandemic, which requires learning to be done online. It is hoped that the dire conditions during the Covid-19 pandemic for the world of education will not make it worse for the state of mathematics education because mathematics learning can still be done with the help of technology in today's digital era. It is in accordance with Malone's expectations, which states that computer games that integrate technology into mathematics classroom learning are introduced to advance mathematics education in the digital era (Bai et al., 2012).

Describing the problem through serial problem exercises by the domino game format provides a useful type of exercise in learning mathematics. These results are in line with the findings of previous studies, which state that the increase in students' conceptual and 
procedural knowledge is an effect of media designed by describing problems visually (Rittle-Johnson \& Star, 2007), thus affecting mathematics achievement and motivation of high school students (Bai et al., 2012). It is under the results of the analysis at the evaluation stage, which shows that the learning carried out effects improving students' mathematical communication ability. The effectiveness of the game instruction type CAI model on improving students' mathematical communication ability in the experimental group proves that the model is suitable for use in mathematics learning.

The results are in line with other similar studies by using successful online discussion to explore and communicate mathematical concepts and foster academic communities in any mathematics course (Johnson \& Green, 2007). The use of tablet PCs has succeeded in developing students' mathematical communication ability through the use of the Sharing Zone function of the Reciprocal Peer-Tutoring-enhanced Mathematical Communication (RPTMC) system (Yang et al., 2016), and the use of GeoGebra, which shows a significant effect on mathematical communication ability compared to conventional mathematics learning (Kusumah et al., 2020).

The CAI type game instruction model that was developed was proven to stimulate student interest in learning, primarily because of the interactive nature of the media and the availability of challenges to play in algebra dominoes. This result is relevant to other research that shows that interactive learning media has a good effect on self-efficacy (Psycharis \& Kallia, 2017), even students' social abilities who are awakened unconsciously based on their mathematical abilities. In this regard, the researcher wants to emphasise the importance of mathematical communication ability as part of the standard mathematical process. Communication ability can affect many things, including everyday life (Yaniawati et al., 2019), including in the context of the increasing need for mathematical literacy in the post-industrial era (Kosko \& Gao, 2017). Optimisation of mathematical communication ability has implications for the active involvement of students in the mathematics learning process. The use of the game type CAI model in this study, namely through the development of comprehensive algebra dominoes, has a strong potential in developing students' mathematical communication ability and other relevant mathematical abilities.

\section{CONCLUSION}

Algebra dominoes developed based on the CAI model type game instruction using Microsoft PowerPoint software have met the standards in the research and development process. The development process is carried out following the ADDIE design, so the development process is carried out in a structured and systematic manner according to the stages in the ADDIE design. The results of the feasibility test show that algebra dominoes are suitable for use in mathematics learning. The results of the validity test conducted by four experts show that the game is suitable for use in learning with the very valid category. The practicality test results in the form of one try out evaluation, small group evaluation, and field evaluation showed that students gave excellent responses to the games developed and students were enthusiastic about learning mathematics which was done with games. At the evaluation stage, the algebra dominoes game is proven to be effective in learning. The results showed that the increase in 
students' mathematical communication ability in the experimental class was better than in the control class. However, the results of this study exposed opportunities to test the effectiveness of the algebra dominoes game on other abilities such as problem-solving, reasoning and proof, connections, and representations in subsequent research.

\section{ACKNOWLEDGEMENT}

On this occasion, the author would like to express we appreciation and gratitude to the Ministry of Education and Culture and the Ministry of Research and Technology/National Agency for Research and Innovation, Directorate of Research and Community Service (DRPM) as a sponsor of the collaborative university research grant scheme, teachers and students of Public Islamic Junior High School called State of Madrasah Tsanawiyah (MTsN) 3 Kuningan, and all those who had a significant impact on success and completion of this study. The authors realise that this article is far from perfect; therefore, constructive criticism and suggestions are needed to achieve this perfection. Hopefully, this research is useful for readers.

\section{REFERENCE}

Anohina, A. (2005). Analysis of the terminology used in the field of virtual learning. Journal of Educational Technology \& Society, 8(3), 91-102. https://www.jstor.org/stable/10.2307/jeductechsoci.8.3.91

Bai, H., Pan, W., Hirumi, A., \& Kebritchi, M. (2012). Assessing the effectiveness of a 3-D instructional game on improving mathematics achievement and motivation of middle school students. British Journal of Educational Technology, 43(6), 993-1003. https://doi.org/10.1111/j.1467-8535.2011.01269.x

Baroody, A. J., \& Coslick, R. T. (1993). Problem solving, reasoning, and communicating, K-8: Helping children think mathematically. Prentice Hall.

Basturk, R. (2005). The effectiveness of computer-assisted instruction in teaching introductory statistics. Journal of Educational Technology \& Society, 8(2), 170-178. https://www.jstor.org/stable/jeductechsoci.8.2.170

Bayraktar, S. (2001). A meta-analysis of the effectiveness of computer-assisted instruction in science education. Journal of Research on Technology in Education, 34(2), 173-188. https://doi.org/10.1080/15391523.2001.10782344

Branch, R. M. (2009). Instructional design: The ADDIE approach (Vol. 722). Springer Science \& Business Media. https://doi.org/10.1007/978-0-387-09506-6

Brendefur, J., \& Frykholm, J. (2000). Promoting mathematical communication in the classroom: Two preservice teachers' conceptions and practices. Journal of Mathematics Teacher Education, 3(2), 125-153. https://doi.org/10.1023/A:1009947032694 
Chang, K.-E., Chen, Y.-L., Lin, H.-Y., \& Sung, Y.-T. (2008). Effects of learning support in simulation-based physics learning. Computers \& Education, 51(4), 14861498. https://doi.org/10.1016/j.compedu.2008.01.007

Christmann, E. P., \& Badgett, J. L. (2000). The comparative effectiveness of CAI on collegiate academic performance. Journal of Computing in Higher Education, 11(2), 91-103. https://doi.org/10.1007/BF02940892

Clark, K. K., Jacobs, J., Pittman, M. E., \& Borko, H. (2005). Strategies for building mathematical communication in the middle school classroom: Modeled in professional development, implemented in the classroom. Current Issues in Middle Level Education, $11(2), 1-12$.

Cooper, B. L., \& Brna, P. (2002). Hidden curriculum, hidden feelings; emotions, relationships and learning with ICT and the whole child. BERA Conference, Exeter, September 2002.

Cuban, L. (2009). Oversold and underused. Harvard university press. https://doi.org/10.2307/j.ctvk12qnw

Davies, B., \& Ellison, L. (1992). School development planning. Longman.

De Jean, J., Upitis, R., Koch, C., \& Young, J. (1999). The story of Phoenix Quest: How girls respond to a prototype language and mathematics computer game. Gender and Education, 11(2), 207-223. https://doi.org/10.1080/09540259920708

De Witte, K., Haelermans, C., \& Rogge, N. (2015). The effectiveness of a computerassisted math learning program. Journal of Computer Assisted Learning, 31(4), 314329. https://doi.org/10.1111/jcal.12090

Erhel, S., \& Jamet, E. (2013). Digital game-based learning: Impact of instructions and feedback on motivation and learning effectiveness. Computers \& Education, 67, 156167. https://doi.org/10.1016/j.compedu.2013.02.019

Ernest, P. (1986). Games. A rationale for their use in the teaching of mathematics in school. Mathematics in School, 15(1), 2-5. https://doi.org/10.1093/teamat/5.3.97

Fraenkel, J. R., Wallen, N. E., \& Hyun, H. H. (2011). How to design and evaluate research in education. New York: McGraw-Hill Humanities/Social Sciences/Languages.

Frederickson, N., Reed, P., \& Clifford, V. (2005). Evaluating web-supported learning versus lecture-based teaching: Quantitative and qualitative perspectives. Higher Education, 50(4), 645-664. https://doi.org/10.1007/s10734-004-6370-0

Funkhouser, C. (2002). The effects of computer-augmented geometry instruction on student performance and attitudes. Journal of Research on Computing in Education, 35(2), 163-175. https://doi.org/10.1080/15391523.2002.10782377 
Gee, J. P. (2005). Learning by design: Good video games as learning machines. ELearning and Digital Media, 2(1), 5-16. https://doi.org/10.2304/elea.2005.2.1.5

González, G. M., \& Birch, M. A. (2000). Evaluating the instructional efficacy of computer-mediated interactive multimedia: Comparing three elementary statistics tutorial modules. Journal of Educational Computing Research, 22(4), 411-436. https://doi.org/10.2190/X8PQ-K0GQ-T2DR-XY1A

Greenes, C., \& Schulman, L. (1996). Communication processes in mathematical explorations and investigations. PC Elliott and MJ Kenney (Eds.).

Haynes, L. C. (2000). Gender differences in the use of a computer-based mathematics game: Strategies, motivation, and beliefs about mathematics and computers.

Heckenberg, S. G., Herbert, R. D., \& Webber, R. (2004). Visualisation of the minority game using a mod. ACM International Conference Proceeding Series, 99, 157-163.

Heshmati, S., Kersting, N., \& Sutton, T. (2018). Opportunities and challenges of implementing instructional games in mathematics classrooms: Examining the quality of teacher-student interactions during the cover-up and un-cover games. International Journal of Science and Mathematics Education, 16(4), 777-796. https://doi.org/10.1007/s10763-016-9789-8

Huang, K. H., \& Ke, C.-J. (2009). Integrating computer games with mathematics instruction in elementary school-An analysis of motivation, achievement, and pupilteacher interactions. World Academy of Science, Engineering and Technology, 60, 992994.

Johnson, E. L., \& Green, K. H. (2007). Promoting mathematical communication and community via blackboard. Primus, 17(4), 325-337. https://doi.org/10.1080/10511970601131563

Ke, F. (2008). Computer games application within alternative classroom goal structures: cognitive, metacognitive, and affective evaluation. Educational Technology Research and Development, 56(5-6), 539-556. https://doi.org/10.1007/s11423-008-9086-5

Kirkley, S. E., \& Kirkley, J. R. (2005). Creating next generation blended learning environments using mixed reality, video games and simulations. TechTrends, 49(3), 4253. https://doi.org/10.1007/BF02763646

Kirkley, S. E., Tomblin, S., \& Kirkley, J. (2005). Instructional design authoring support for the development of serious games and mixed reality training. Interservice/Industry Training, Simulation and Education Conference. https://doi.org/10.1.1.91.7385

Kosko, K. W., \& Gao, Y. (2017). Mathematical communication in state standards before the common core. Educational Policy, 31(3), 275-302. https://doi.org/10.1177/0895904815595723 
Koster, R. (2013). Theory of fun for game design. "O'Reilly Media, Inc.”

Kusumah, Y. S., Kustiawati, D., \& Herman, T. (2020). The Effect of GeoGebra in Three-Dimensional Geometry Learning on Students' Mathematical Communication Ability. International Journal of Instruction, 13(2), 895-908. https://doi.org/10.29333/iji.2020.13260a

Lopez-Morteo, G., \& López, G. (2007). Computer support for learning mathematics: A learning environment based on recreational learning objects. Computers \& Education, 48(4), 618-641. https://doi.org/10.1016/j.compedu.2005.04.014

Macaruso, P., \& Walker, A. (2008). The efficacy of computer-assisted instruction for advancing literacy skills in kindergarten children. Reading Psychology, 29(3), 266-287. https://doi.org/10.1080/02702710801982019

Munir, Kusnendar, J., \& Rahmadhani. (2016). Developing an effective multimedia in education for special education (MESE): An introduction to arithmetic. AIP Conference Proceedings, 1708(1), 50001. https://doi.org/10.1063/1.4941159

NCTM. (2000). Principles and standards for school mathematics (Vol. 1). National Council of Teachers of.

Nejem, K. M., \& Muhanna, W. (2013). The effect of using computer games in teaching mathematics on developing the number sense of fourth grade students. Educational Research and Reviews, 8(16), 1477-1482. https://doi.org/10.5897/ERR012.143

Newby, T. J., Stepich, D. A., Russell, J. D., \& Lehman, J. D. (2006). Educational technology for teaching and learning. Prentice Hall.

Pennington, R. C. (2010). Computer-assisted instruction for teaching academic skills to students with autism spectrum disorders: A review of literature. Focus on Autism and Other Developmental Disabilities, 25(4), 239-248.

Pilli, O., \& Aksu, M. (2013). The effects of computer-assisted instruction on the achievement, attitudes and retention of fourth grade mathematics students in North $\begin{array}{lllll}\text { Cyprus. } & \text { Computers } \quad \& \quad \text { Education, 62-71. }\end{array}$ https://doi.org/10.1016/j.compedu.2012.10.010

Plowman, L., \& Stephen, C. (2003). A 'benign addition'? Research on ICT and preschool children. Journal of Computer Assisted Learning, 19(2), 149-164. https://doi.org/10.1046/j.0266-4909.2003.00016.x

Prensky, M. (2001). Digital Game-Based Learning. McGraw-Hill.

Psycharis, S., \& Kallia, M. (2017). The effects of computer programming on high school students' reasoning skills and mathematical self-efficacy and problem solving. Instructional Science, 45(5), 583-602. https://doi.org/10.1007/s11251-017-9421-5 
Richards, C. (2005). The design of effective ICT-supported learning activities: Exemplary models, changing requirements, and new possibilities. Language Learning \& Technology, 9(1), 60-79.

Rittle-Johnson, B., \& Star, J. R. (2007). Does comparing solution methods facilitate conceptual and procedural knowledge? An experimental study on learning to solve equations. Journal of Educational Psychology, 99(3), 561. https://doi.org/10.1037/0022-0663.99.3.561

Rubenstein, R. N., \& Thompson, D. R. (2002). Understanding and supporting children's mathematical vocabulary development. Teaching Children Mathematics, 9(2), 107-113.

Sanchez-Palencia, E. (1980). Non-homogeneous Media and Vibration Theory, Lecture Notes in Physics, vol. 127, Springer, Berlin, 1980.

Sudarsana, I. K., Lestari, N. G. A. M. Y., Wijaya, I. K. W. B., Krisdayanthi, A., Andayani, K. Y., Trisnadewi, K., Muliani, N. M., Dewi, N. P. S., Suparya, I. K., Gunawan, I. G. D., \& others. (2020). Covid-19: Perspektif Pendidikan. Yayasan Kita Menulis.

Thomas, L., \& Knezek, D. (2002). Standards for technology-supported learning environments. The State Education Standard, 3(3), 14-20.

Tobias, S., Fletcher, J. D., Dai, D. Y., \& Wind, A. P. (2011). Review of research on computer games. Computer Games and Instruction, 127, 222.

Umbara, U., Munir, M., Susilana, R., \& Puadi, E. F. W. (2019). Increase Representation in Mathematics Classes: Effects of Computer Assisted Instruction Development with Hippo Animator. International Electronic Journal of Mathematics Education, 15(2), em0567. https://doi.org/10.1088/1742-6596/1521/3/032010

Umbara, U., Munir, Susilana, R., \& Puadi, E. F. W. (2020). The applicationof ICT learning through Hippani: the effects on mathematical reasoning ability. Journal of Physics: Conference Series, 1521, 32010. https://doi.org/10.29333/iejme/6262

van Oostendorp, H., der Spek, E. D., \& Linssen, J. (2014). Adapting the Complexity Level of a Serious Game to the Proficiency of Players. EAI Endorsed Trans. Serious Games, 1(2), e5. https://doi.org/10.4108/sg.1.2.e5

Whitin, P., \& Whitin, D. J. (2003). Developing Mathematical Understanding along the Yellow Brick Road. Young Children, 58(1), 36-40.

Yang, E. F. Y., Chang, B., Cheng, H. N. H., \& Chan, T.-W. (2016). Improving pupils' mathematical communication abilities through computer-supported reciprocal peer tutoring. Journal of Educational Technology \& Society, 19(3), 157-169. https://www.jstor.org/stable/10.2307/jeductechsoci.19.3.157 
Yaniawati, R. P., Indrawan, R., \& Setiawan, G. (2019). Core Model on Improving Mathematical Communication and Connection, Analysis of Students' Mathematical Disposition. International Journal of Instruction, 12(4), 639-654. https://doi.org/10.29333/iji.2019.12441a

Zhang, L., Watson, E. M., \& Banfield, L. (2007). The efficacy of computer-assisted instruction versus face-to-face instruction in academic libraries: a systematic review. The Journal of Academic Librarianship, 33(4), 478-484. https://doi.org/10.1016/j.acalib.2007.03.006 